\title{
Changes in Language Use in the Future
}

\author{
Guanzheng Zhang \\ North China Electric Power University, Baoding 071000, China; \\ 1194533191@qq.com
}

Keywords: language speakers, establishing offices

\begin{abstract}
Language is the basic way to promote the communication and cooperation among countries. This paper studied the number and geographic distribution of language speakers over time, aimed to make an optimal recommendation for the company on the choice of the location and number of the offices. It starts with a map of the world divided into the main areas of each language. Considering the dispersion of linguistic geographic distribution, a Cellular Automaton Model is formulated to simulate the geographic distribution and the trend of language change. To take other factors into account, PCA is adopted to improve the model. Based on the results of the model, this paper preliminary estimates that English speakers will continue to account for the largest proportion and Chinese speakers have marginal increase. Spanish and Hindi speakers can be up and down. Arabic and the remaining small languages are on declining curves. The migration patterns evolve towards the direction from backward areas like the Middle East to developed countries. And what this paper has found in references further confirm our predictions. Punjabi can be replaced according to our analysis. Then, AHP is applied to find the six most suitable countries, England, France, Germany, Japan, India and Brazil, respectively. Global communication, traced to its cause, depends on the development of language. Languages are gradually unified and with the increment of communication modes and it are not necessary to open more than six offices around the world. But to be more closely to the practical situation, this paper discusses the additional influence such as the business scope and the size of the company.
\end{abstract}

\section{Introduction}

Protection of language diversity is an issue that should be highly aware of. Language is the most direct way to communicate with the outside world and to some extent, it can reflect the comprehensive strength of a country and it is the most powerful tool for preserving and developing the physical and intangible heritage of humanity.

Give an example in England; between the thirteenth and fifteenth centuries, there happened many incidents that had significant impacts on English development, which can be divided into social factors, language factors and communication carriers factors, promoting the development of English gradually evolved into today's international language. Though England does not have particularly large population, but English has a considerable influence on the world.

And each language shows a kind of attribution and symbol, which is the main method of distinguishing it from other ethnic groups. The wisdom, religion, customs and history of a nation are deeply implied in their language. Therefore, language has always been recognized as the most typical feature of mankind.

There exist about 6900 languages in the world. A language disappears every 15 days. At this rate, unless effective protection measures are taken against the rich and colorful ethnic and cultural heritage of the world, many people in the country will speak their native languages in the next century. However, the working and communicative languages will be forced to be replaced by "foreign languages." 
The number of language speakers is relevant to many factors covering almost all the aspects. As a whole, the world languages are developing in a simple and meticulous way, mainly by simplifying and integrating language grammar, adding foreign words and creating new words to adapt to a new era of keeping pace with the times.

\section{Organization of the Text}

\subsection{Construction of Cellular Automata Model}

In this section, we aim to build a model simulate the distribution of various language speakers related to time. Inspired by the diffusion model of biome, we consider to adopt Cellular Automaton Model(CA). It is generally used to solve problems that are discrete in space and time and it is effective to solve prediction type of problems.

\subsection{General Assumption}

(1) Peoples language well be assimilated by surrounding languages if the number is big enough.

(2) Regardless of impacts on the number of unpredictable events because the probability of their occurrence is random.

(3) The probability of each country choosing to learn a language is the same. Because the situation that a region does not learn language because of poverty can seldom happen.

(4) We neglect the situation of the area junction. And it is feasible because the influences are fairly small.

\subsection{Determination of Influencing Factors}

\begin{tabular}{|c|c|c|c|c|c|c|c|c|}
\hline - & & $\begin{array}{c}\text { Zscore: The } \\
\text { number of } \\
\text { native } \\
\text { speakers }\end{array}$ & $\begin{array}{l}\text { Zscore: The } \\
\text { number of } \\
\text { publications }\end{array}$ & $\begin{array}{l}\text { Zscore: } \\
\text { Number of } \\
\text { foreign } \\
\text { students }\end{array}$ & Zscore(GDP) & $\begin{array}{c}\text { Zscore: The } \\
\text { number of } \\
\text { innbound } \\
\text { tourists }\end{array}$ & $\begin{array}{l}\text { Zscore: The } \\
\text { content of the } \\
\text { website } \\
\text { language } \\
\text { ratio }\end{array}$ & $\begin{array}{l}\text { Zscore: The } \\
\text { proportion of } \\
\text { the total } \\
\text { number of } \\
\text { immigrants in } \\
\text { the world }\end{array}$ \\
\hline & $\begin{array}{l}\text { Zscore: The number of } \\
\text { native speakers }\end{array}$ & 1.000 & .685 & .178 & .428 & .371 & -.035 & .028 \\
\hline & $\begin{array}{l}\text { Zscore: The number of } \\
\text { publications }\end{array}$ & .685 & 1.000 & .827 & .936 & .504 & .693 & .675 \\
\hline 1 & $\begin{array}{l}\text { Zscore: Number of } \\
\text { foreign students }\end{array}$ & .178 & .827 & 1.000 & .948 & .412 & .969 & .964 \\
\hline & Zscore(GDP) & .428 & .936 & 948 & 1.000 & .494 & .877 & .852 \\
\hline & $\begin{array}{l}\text { Zscore: The number of } \\
\text { innbound tourists }\end{array}$ & .371 & .504 & .412 & .494 & 1.000 & .421 & .441 \\
\hline & $\begin{array}{l}\text { Zscore: The content of } \\
\text { the website language } \\
\text { ratio }\end{array}$ & -.035 & .693 & .969 & .877 & .421 & 1.000 & .985 \\
\hline & $\begin{array}{l}\text { Zscore: The proportion of } \\
\text { the total number of } \\
\text { immigrants in the world }\end{array}$ & -.028 & .675 & .964 & .852 & .441 & .985 & 1.000 \\
\hline
\end{tabular}

Figure 1 Correlation Matrix

Step one, we pick out some representative aspects as the research direction to analyze the trend of language speakers change. We consider the following seven aspects.

\section{Cellular Automaton Model}

We formulate cellular automaton model to model the distribution of various language speakers over time. When the algorithm is in use, we need to make clear the following points:

(1) Structure: How to abstracts a space model as cells;

(2)Rule: How to define the state of the cell according to the last point in time and updated rules of their neighbors states; 
(3)Neighbor: How to define each cell's neighbor;

Effectively, CA Model is built on a state transfer function. The establishment of the focus is on the formulation of the rules. So it is crucial to ascertain the dynamics of the cell state at the next moment based on the cell's current states and the condition of the neighbors.

We start with a map of the world divided into the main areas of each language.

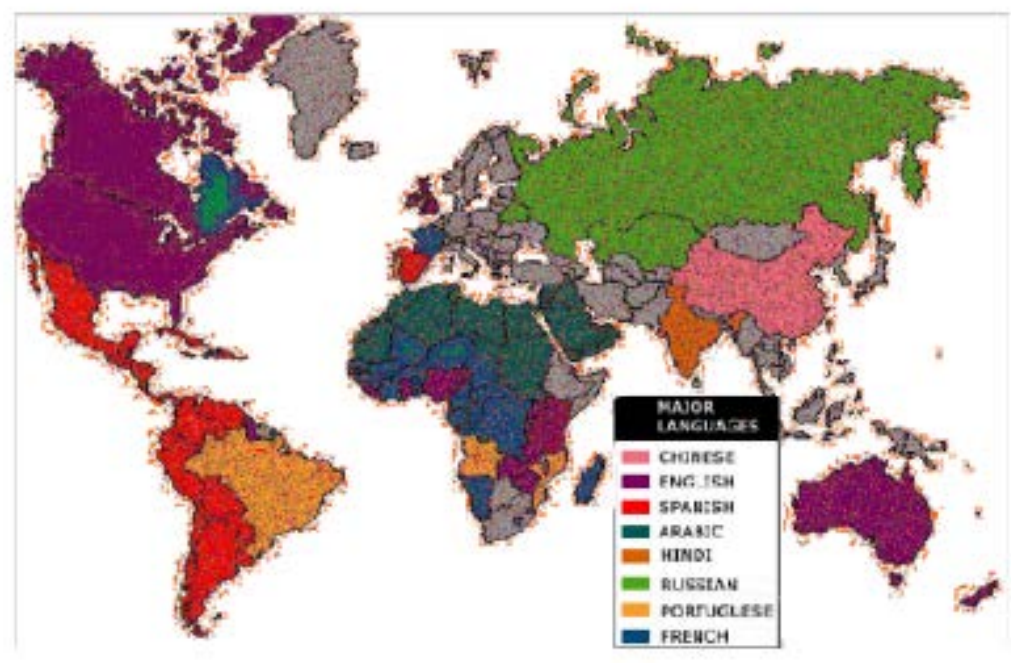

Figure 2 The map of the world

\section{Geographic Distributions Prediction}

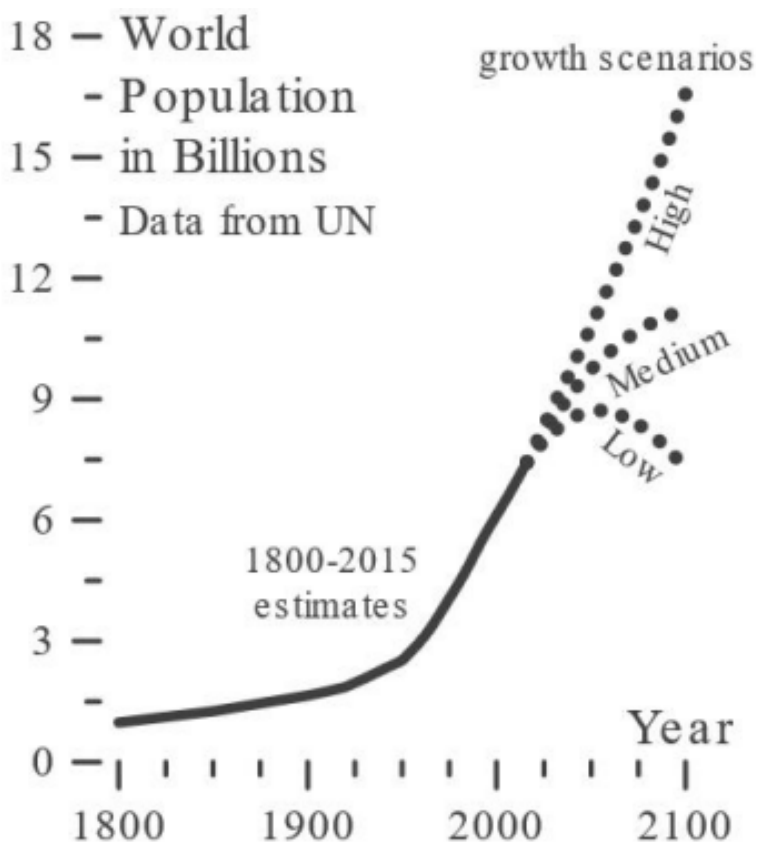

Figure 3 Global Population Prediction

Our model appears to be practical and concise to judge whether the geographic distributions of these languages will change. On the face of simulation results, distribution of English speakers gradually occupies other areas and is continuing to spread. Some small language districts tend to shrink. To make the demonstration more powerful, provide the graph of global population prediction and some figures of human migration pattern.

As shown in the figure: The global population can be considered as growing steadily for the next fifty years. 


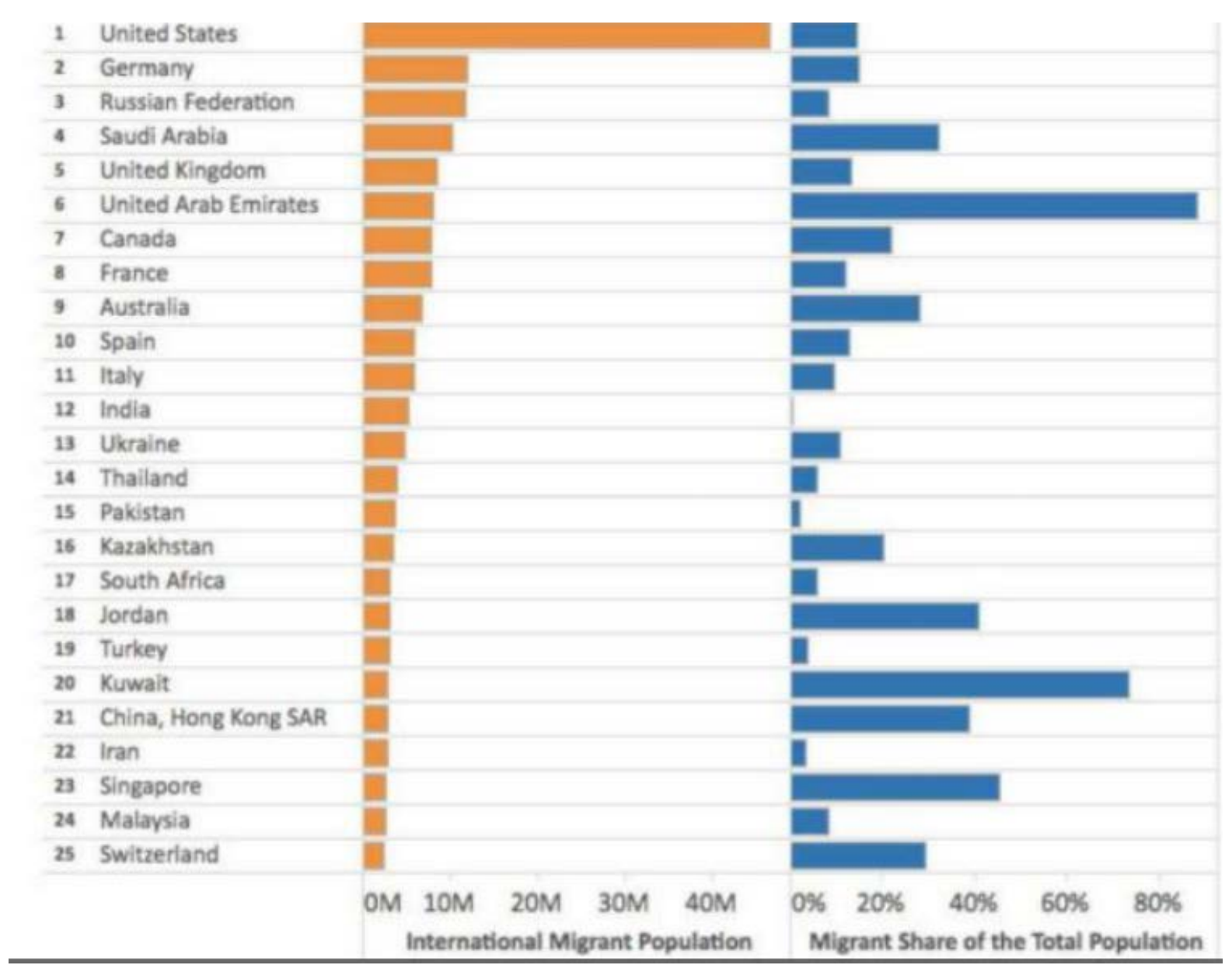

Figure 4 Destination Countries for International Migration

\section{Summary}

We can visualize the trend of the distribution and get the very intuitional conclusion. The model shows the variation trend of the language speaker's number and the geographic distribution simultaneously, so it is practical. The model can predict the long-term tendency.

\section{References}

[1] “World Population Prospects-Population Division-United Nations”.esa.un.org. Retrieved 2017-11-29.

[2] Internal Migration Data around the World: Assessing Contemporary Practice. Population Space Place ,published online in Wiley Online Library.

[3] Campbell, Lyle, Lee, Nala Huiying Okura , Eva; Sipmon ,Sean; Ueki ,Kaori.2003. 